лен высокий процент условно-патогенной микрофлоры, значительное уменьшение лакто- и бифидобактерий, что требует коррекции с целью улучшения качества жизни женщин.

Ключевые слова: постменопауза, урогенитальные нарушения, биоценоз.

\title{
THE STUDY OF VAGINAL MICROBIOCENOSIS IN WOMEN DURING MENOPAUSE
}

\section{S.Y. Kosilova}

Abstract. A considerable decrease of estrogen levels is known to be characteristic for postmenopause. Estrogen deficiency becomes evident due to numerous clinical signs. These signs include urogenital disorders. Complicated obstetricalgynecological anamnesis and increased frequency of extragenital diseases are found to occur more often in women with urogenital disorders. These patients manifest a high percentage of opportunistic microflora, considerable decrease of lactoand bifidus bacteria, requiring correction with the aim to improve the quality of life of women.

Key words: postmenopause, urogenital disorders, biocenosis.

Bukovinian State Medical University (Chernivtsi)

Рецензент - доц. С.М. Ясніковська

Buk. Med. Herald. - 2015. - Vol. 19, № 2 (74). - P. 111-113

Надійшла до редакції 05.02.2015 року

(C) С.Е. Косілова, 2015

УДК 618.173-07-085

С.Е. Косілова

\section{НЕГОРМОНАЛЬНА КОРЕКЦІЯ КЛІМАКТЕРИЧНИХ РОЗЛАДІВ У ЖІНОК У ПОСТМЕНОПАУЗІ}

Буковинський державний медичний університет, м. Чернівці

Резюме. У постменопаузі має місце гормональний дисбаланс: підвищується рівень гонадотропних гормонів і знижується рівень естрадіолу. Це призводить до розвитку клімактеричного синдрому, порушення якості життя жінок. Оскільки до замісної гормонотерапії є багато протипоказів, з метою корекції проявів клімактеричного синдрому пропонується застосування рослинного препа- рату Естрелла. У результаті дослідження з'ясовано, що даний препарат ефективно купірує прояви клімактеричного синдрому, не здійснює негативного впливу на ендо-, міометрій, яєчники і молочні залози.

Ключові слова: постменопауза, гормональний дисбаланс, клімактеричний синдром.
Вступ. Незважаючи на значні успіхи, досягнуті в гінекологічній ендокринології, більшість проблем, пов'язаних зі змінами гормонального статусу в різні вікові періоди залишається невирішеними. За даними літератури, частота паталогічного перебігу клімактеричного періоду коливається від 73 до $85 \%$ [1, 2, 5, 6, 7]. У цей період погіршується самопочуття жінки, знижується іiі працездатність і якість життя. Відбуваються зміни в гіпоталамо-яєчниковій системі, які характеризуються «десинхронізацією» процесів у гіпоталамусі. Рівень гонадотропінів підвищується, а рівень естрогенів поступово знижується. Дефіцит статевих гормонів проявляється в ранніх (60$80 \%$ ), середньочасових (30-50\%), пізніх обміних (25-40\%) і дуже пізніх обміних (5-12 \%) порушеннях $[4,5,6,8]$. Корекцію цих порушень доцільно розпочинати як можна раніше. Відомо, що найбільш ефективною в цьому напрямку є гормонотерапія. Але в більшості випадків гормонотерапія протипоказана. Вона протипоказана жінкам 3 наявністю екстрагенітальних захворювань, пухлин і гіперпроліферативних процесів у репродук- тивній системи (збільшується ризик розвитку онкологічних захворювань). Крім того, частина жінок упереджено ставиться до гормональних препаратів $[1,2,3,7]$. Перспективним рішенням цієї проблеми є призначення жінкам у період менопаузи негормональних препаратів, які б проводили корекцію дисгормональних розладів, що розпочались.

Мета дослідження. Оцінити ефективність лікування клімактеричних розладів у постменопаузі рослинним препаратом Естрелла.

Матеріал і методи. Дослідження проводилось у 40 жінок, віком від 45 до 55 років з наявністю „типової” форми клімактеричного синдрому (КС). Усі пацієнтки проходили клінічнолаболаторне обстеження. У них вивчали загальноклінічні і локальні симптоми, скарги, вегетативні та нейропсихічні розлади, органічний симптомокомплекс. До і після прийому препаратів визначали рівень гормонів (ЛГ, ФСТ, естрадіол, прогестерон) методом радіоімунного аналізу.

Тяжкість загального стану жінок, вираженість КС (психоемоційні, нейровегетативні, об- 
мінноендокринні порушення) оцінювали до початку лікування та через три - шість місяців лікування за менопаузальним індексом (MMI) Купермана в модифікації Е.В.Уварової. Якість життя пацієнток визначали у балах до, та через три шість місяців лікування на підставі самооцінки своєї задоволеності здоров'ям, розумовими здібностями, працездатністю, сексуальними стосунками (незадовільно - 0 балів; задовільно - 1 бал).

Особлива увага приділялася вивченню впливу запропонованої терапії на органи-мішені (ендо- і міометрій, яєчники, молочні залози). Стан молочних залоз вивчали на підставі оцінки суб'єктивних відчуттів, ультразвукового дослідження або мамографії. Стан яєчників і матки вивчали за допомогою ультразвукового дослідження органів малого таза до, та через три, шість місяців лікування. Вивчали розміри матки та товщу ендометрія, зміни в яєчниках.

Жінки отримували рослинний препарат Естрелла у вигляді спрею по п'ять розпилювань вранці та по чотири - ввечері, під язик щодня впродовж трьох місяців. Естрелла містить 8,5 мг транс-ресвератролу (фітоестроген із коренів гірчака гребінчастого, подібний до естрадіолу), 12 мг вітаміну E, 10 мг вітаміну $\mathrm{D}_{3}$. Завдяки унікальному сполученню фітоестрогену, вітамінів $\mathrm{E} \mathrm{i}_{3}$ Естрелла пом'якшує симптоми клімаксу, проводить профілактику остеопорозу, ускладнень із боку серцево-судинної, нервової та ендокринної систем, сприяє покращанню стану шкіри, волосся та нігтів.

Результати дослідження та їх обговорення. На початку спостереження за ступенем тяжкості клімактеричного синдрому, залежно від модифікованого менопаузального індексу в 30 \% жінок був слабкий ступінь тяжкості КС (12-34 бали), у $60 \%$ - помірний (35-58 балів), у $10 \%$ - тяжкий ступінь (58 і більше балів). Нейровегетативні та психоемоційні розлади мали місце у всіх пацієнток, метаболічні - у 30 \%.

Так, перед початком лікування припливи легкого ступеня мали місце в 13 (32,5\%) пацієнток, середнього ступеня - у 20 (50 \%), тяжкого у 7 (17,5 \%). Вже через три місяці від початку лікування прояви вегето-судинних порушень значно зменшились. Припливи легкого ступеня залишились у 2 (5\%) хворих, середнього ступеня у $10(25 \%)$, тяжкого - у 4 (10\%). Через шість місяців лікування жінки з легким і середнім ступенем припливів не мали скарг. У трьох обстежених із тяжким ступенем спостерігалися припливи, але вони були менш виражені.

Подібний лікувальний ефект мав місце відносно до пітливості, яка до початку лікування спостерігалася: легкого ступеня - в 11 жінок (27,5\%), середнього - у 20 (50\%), тяжкого - у 9 $(22,5 \%)$. Через півроку лікування лише в трьох пацієнток зберігалася слабка пітливість.

Був проаналізований вплив препарату Естрелла на симптомокомплекс, який проявляється психогенними і емоційними симптомами: дратівливість, безсоння, швидка втомлюваність, невротичні прояви та інше. Виявлена позитивна динаміка психоемоційного стану хворих. Так, дратівливість і внутрішня напруга спостерігалася рідше на $75 \%$, плаксивість - на $60 \%$, депресивні стани - на $40 \%$.

Таким чином, що вже через три місяці застосування запропонованої терапії в пацієнток відмічалося значне зниження модифікованого менопаузального індексу: нейровегетативних розладів на $60 \%$, психоемоційних - на $58 \%$, обмінноендокринних - на 40 \%. Через шість місяців вказані порушення були купіровані на $90 \%(\mathrm{p}<0,05)$, $75 \%(\mathrm{p}<0,05)$ і $65 \%(\mathrm{p}<0,05)$ відповідно. У результаті проведеного лікування поступово покращився загальний стан хворих, неухильно поліпшувалася якість життя. Так, через шість місяців від початку лікування сумарна оцінка якості життя пацієнток порівнянно 3 початковою зросла у 2,5 раза, в основному за рахунок підвищення задоволеності своїм здоров'ям, працездатністю, сімейними відносинами.

Наприкінці лікування спостерігалося зниження рівня гонадотропних гормонів і підвищення рівня естрадіолу і прогестерону до рівня ранньої фолікулінової фази циклу. Рівень ФСГ зни-

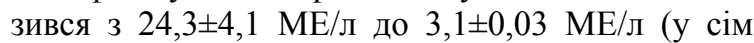

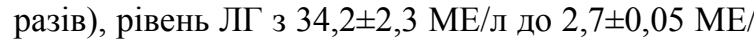
л (у 12 разів), p<0,05. На тлі зниження ФСГ, ЛГ i тенденції до підвищення естрадіолу каріопікнотичний індекс збільшився в середньому у два рази, що відповідає даним літератури [2, 3, 8, 9].

За весь період терапії в жодної з пацієнток негативної динаміки $з$ боку молочних залоз не виявлено.

Через три і шість місяців лікування проводився ультразвуковий і гістологічний контроль ендометрія. У пацієнток не виявлено змін розмірів матки і яєчників. Товща ендометрія суттєво не змінювалась і складала на 6-му місяці 0,36 $\pm 0,4$ см.

\section{Висновки}

1. Препарат Естрелла дозволяє провести корекцію дисгормональних розладів, які супроводжують згасання оваріальної функції і викликають прояви клімактеричного синдрому.

2. Застосування рослинного препарату Естрелла в жінок у постменопаузі ефективно купірує нейровегетативні, психоемоційні та обмінноендокринні симптоми, забезпечуючи тим самим значне поліпшення загального стану і якості життя пацієнток.

3. Рослинний препарат Естрелла в жінок 3 інтактною маткою в постменопаузі не здійснює негативного впливу на ендо-, міометрій, яєчники і молочні залози.

4. Терапія препаратом Естрелла в жінок у постменопаузі $є$ безпечною і добре переноситься.

Перспективи подальших досліджень. Проведення аналізу дії препарату Естрелла в жінок 3 урогенітальними порушенями в постменопаузі. 


\section{Література}

1. Бутіна Л.І. Профілактика нейро- вегетативних та психоемоційних порушень в менопаузі у жінок з гіперпроліферативними процесами репродуктивної системи / Л.І. Бутіна // Зб. наук. пр. Асоц. акуш.-гінек. України. - 2011. - С. 62-65.

2. Герасимова Т.В. Негормональная коррекция эстрогендефицитных состояний / Т.В. Герасимова, Н.В. Слинчук // Зб. наук. пр. Асоц. акуш.-гінек. України. - 2011. - C. 148-152.

3. Задорожна О.Б. Немедикаментозна терапія у комплексному лікуванні клімактеричного синдрому / О.Б. Задорожна, О.Д. Телющенко, А.І. Лучков // Зб. наук. пр. Асоц. акуш.-гінек. України. - 2010. - С. 288-291.

4. Золотухин Н.С. Течение климактерического периода у жительниц сельскохозяйственного региона / Н.С. Золотухин, А.В. Чурилов, Л.И. Бутина // Зб. наук. пр. Асоц. акуш.-гінек. України. - 2009. - С. 303-305.
5. Луценко Н.С. Климактерический синдром с позиции старения и витаукта / Н.С. Луценко, И.В. Ломака, И.Н. Кириченко // Вісн. Асоц. акуш.-гінек. України. 2010. - № 4. - С. 35-38.

6. Руководство по климактерию: Руководство для врачей / под ред. В.П. Сметник, В.И. Кулакова. - М.: Медицинское информационное агенство, 2009. - 175 с.

7. Стрижова Н.В. Сравнительная характеристика эффективности лечения климактерического синдрома гормональными и комплексными гомеопатическими препаратами / Н.В. Стрижова, О.А. Нестерова // Вестн. Рос. Ассоциации акушеров-гинекологов. 2010. - № 4. - C. 52-56.

8. Ettinger B. Reduced mortality associated with long-term postmenopausal esterogentherapy / B. Ettinger, T. Bush // Obstet. Gynecol. - 2008. - № 87. - P. 6-12.

\section{НЕГОРМОНАЛЬНАЯ КОРРЕКЦИЯ КЛИМАКТЕРИЧЕСКИХ НАРУШЕНИЙ У ЖЕНЩИН В ПОСТМЕНОПАУЗЕ}

\section{С.Е. Косилова}

Резюме. В постменопаузе имеет место гормональный дисбаланс: повышается уровень гонадотропных гормонов и снижается уровень эстрадиола. Это приводит к развитию климактерического синдрома, нарушению качества жизни женщин. Так как к заместительной гормонотерапии имеется много противопоказаний, с целью коррекции проявлений климактерического синдрома предлагается использование растительного препарата Эстрелла. В результате исследования установлено, что данный препарат эффективно купирует проявления климактерического синдрома, не оказывает отрицательного влияния на ендо-, миометрий, яичники и молочные железы.

Ключевые слова: постменопауза, гормональный дисбаланс, климактерический синдром.

\section{NONHORMONAL CORRECTION OF CLIMACTERIC DISORDERS IN WOMEN DURING POSTMENOPAUSE}

\section{S.Y. Kosilova}

Abstract. Postmenopause is characterized by hormonal imbalance: the level of gonadotropic hormones increases and the level of estradiol decreases. It results in the development of climacteric syndrome, disorders of the life quality of women. Due to the fact that replacement hormonal therapy has many contraindications, with the aim to correct the signs of climacteric syndrome the use of the plant medicine Estrella is suggested. The study has found that this medicine effectively terminates the signs of climacteric syndrome, does not have any negative influence upon the endo-, myometrium, ovaries and mammary glands.

Key words: postmenopause, hormonal imbalance, climacteric syndrome.

Bukovinian State Medical University (Chernivtsi)

Рецензент - д.мед.н. І.В. Каліновська
Buk. Med. Herald. - 2015. - Vol. 19, № 2 (74). - P. 113-115

Надійшла до редакції 05.02.2015 року

(C) С.Е. Косілова, 2015 